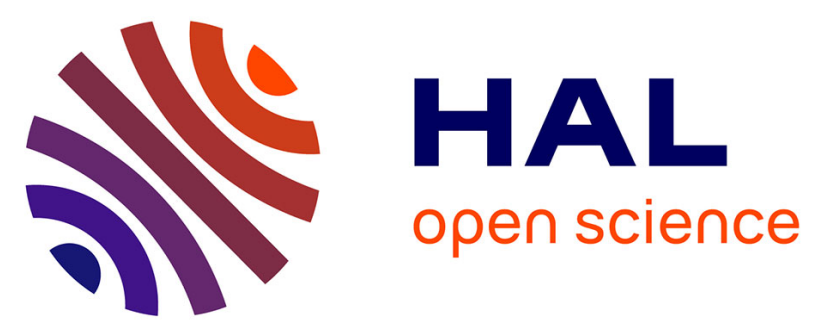

\title{
The afterlife of Egyptian statues: a cache of religious objects in the temple of Ptah at Karnak
}

Guillaume Charloux, Christophe Thiers, Mohamed Abd Al-Aziz, Mona Abady

Mahmoud, Stéphanie Boulet, Camille Bourse, Kevin Guadagnini, Juliette Laroye, Ahmed Mohamed Sayed Elnasseh

\section{To cite this version:}

Guillaume Charloux, Christophe Thiers, Mohamed Abd Al-Aziz, Mona Abady Mahmoud, Stéphanie Boulet, et al.. The afterlife of Egyptian statues: a cache of religious objects in the temple of Ptah at Karnak. Antiquity, 2017, 91 (359), pp.1189-1204. 10.15184/aqy.2017.137 . halshs-01591970

\section{HAL Id: halshs-01591970 \\ https://shs.hal.science/halshs-01591970}

Submitted on 17 Jan 2020

HAL is a multi-disciplinary open access archive for the deposit and dissemination of scientific research documents, whether they are published or not. The documents may come from teaching and research institutions in France or abroad, or from public or private research centers.
L'archive ouverte pluridisciplinaire HAL, est destinée au dépôt et à la diffusion de documents scientifiques de niveau recherche, publiés ou non, émanant des établissements d'enseignement et de recherche français ou étrangers, des laboratoires publics ou privés. 
EDITOR

Chris Scarre

\section{REVIEWS EDITOR}

Robert Witcher

\section{Editorial Manager \\ Jo Dean}

\section{EDITORIAL Assistants}

Ross Kendall

Thomas Swindells

James Walker

Media Assistant

Tom Horne

EDITORIAL ADDRESS

Antiquity, Dept. of Archaeology,

Durham University, South Road, Durham DH1 3LE, UK

Tel: +44 (0) 191 3341125; Fax: +44 (0) 191 3341101; Email: editor@antiquity.ac.uk

Antiquity is an international peer-reviewed journal of archaeological research that aims to communicate the most significant discoveries, theory, method and cultural resource issues rapidly and in plain language to practising archaeologists everywhere.

Antiquity is included in the Cambridge Journals Online service at http://journals.cambridge.org/AQY. Additional content, the Project Gallery, and free-to-access material may be found at http://antiquity.ac.uk

Antiquity was founded in 1927 by O.G.S. Crawford and is owned by the Antiquity Trust, a registered charity. The trustees of the Antiquity Trust are Graeme Barker, Amy Bogaard, Robin Coningham, Barry Cunliffe, Roberta Gilchrist, Anthony Harding, Paul Mellars, Martin Millett, Nicky Milner, Stephanie Moser and Cameron Petrie.

The Directors of Antiquity Publications Ltd, owned by the Antiquity Trust and responsible for producing Antiquity are Chris Gosden, Nicky Milner, Cameron Petrie, Mike Pitts and Chris Scarre.

\section{EDITORIAL ADVISORY BOARD}

Peter Bellwood, The Australian National University, Australia Barbara Mills, University of Arizona, USA

Xingcan Chen, Chinese Academy of Social Sciences, Beijing

Peter Mitchell, University of Oxford, UK

Eduardo Goés Neves, Universidade de São Paulo, Brazil

Elizabeth Graham, University College London, UK

Timothy Pauketat, University of Illinois, USA

Christine Hastorf, University of California Berkeley, USA

Charles Higham, University of Otago, New Zealand

Stephen Houston, Brown University, USA

Timothy Insoll, University of Exeter, UK

Susan Keech McIntosh, Rice University, USA

Ian Kuijt, University of Notre Dame, USA

Victor Paz, University of The Philippines, The Philippines

Michael Petraglia, Max Planck Institute for the Science of

Human History, Jena, Germany

Innocent Pikirayi, University of Pretoria, South Africa

Susan Pollock, Freie Universität Berlin, Germany

Natalia Shishlina, State Historical Museum, Moscow, Russia

Benjamin Smith, University of Western Australia, Australia

Kevin Lane, Universidad de Buenos Aires, Argentina

Li Liu, Stanford University, USA

Akira Matsuda, University of Tokyo, Japan

Claire Smith, Flinders University, Australia

Monica Smith, University of California, Los Angeles, USA

Melinda Zeder, Smithsonian Institution, USA

Antiquity is published six times a year by Cambridge University Press for Antiquity Publications Ltd; February, April, June, August, October, December.

Advertising enquiries to the publisher at advertising@cambridge.org

(C)Antiquity Publications 2017. All rights reserved. No part of this publication may be reproduced, in any form or by any means, electronic, photocopying or otherwise, without permission in writing from Cambridge University Press. Permission to copy (for users in the USA) is available from Copyright Clearance Center, http://www.copyright.com, email: info@copyright.com.

This journal issue has been printed on FSC ${ }^{\mathrm{TM}}$-certified paper and cover board. FSC is an independent, nongovernmental, not-for-profit organization established to promote the responsible management of the world's forests. Please see www.fsc.org for information.

Printed by Bell \& Bain Limited, Glasgow, UK.

Design: Barry Perks (www.yo-yo.uk.com)

Typesetting: Aptara Inc, New Delhi, India

Subscriptions can be purchased from Cambridge University Press and online at https://www.cambridge.org/core/journals/ antiquity/subscribe

Front cover: Conservation of an Osiris statuette from the temple of Ptah at Karnak (C CFEETK-CNRS-MoA/J. Maucor). 
ANT

Volume 91

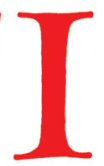

Q
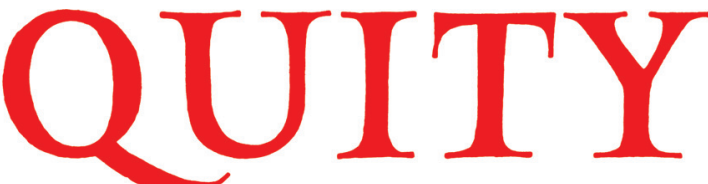

Number 359

\section{October 2017}

\section{Editorial}

\section{Research}

Radiocarbon dating of human burials from Raqefet Cave and contemporaneous

Natufian traditions at Mount Carmel

Omry Barzilai, Noemi Rebollo, Dani Nadel, Fanny Bocquentin, Reuven Yeshurun,

György Lengyel, Gal Bermatov-Paz \& Elisabetta Boaretto

Hafting with beeswax in the Final Palaeolithic: a barbed point from Bergkamen

Michael Baales, Susanne Birker \& Frank Mucha

Islands of history: the Late Neolithic timescape of Orkney

Alex Bayliss, Peter Marshall, Colin Richards \& Alasdair Whittle

The afterlife of Egyptian statues: a cache of religious objects in the temple of

Ptah at Karnak

Guillaume Charloux, Christophe Thiers, Mohammad Abd Al-Aziz,

Mona Ali Abady Mahmoud, Stéphanie Boulet, Camille Bourse, Kevin Guadagnini, Juliette Laroye \& Ahmed Mohammed Sayed ElNasseh

Tracing textile cultures of Italy and Greece in the early first millennium BC Margarita Gleba

Emptyscapes: filling an 'empty' Mediterranean landscape at Rusellae, Italy

Stefano Campana

Bayesian analysis and free market trade within the Roman Empire

Xavier Rubio-Campillo, María Coto-Sarmiento, Jordi Pérez-Gonzalez \&

José Remesal Rodríguez

Depletion gilding, innovation and life-histories: the changing colours of Nahuange metalwork

Juanita Sáenz-Samper \& Marcos Martinón-Torres

Understanding the layout of early coastal settlement at Unguja Ukuu, Zanzibar

Tom Fitton \& Stephanie Wynne-Jones

Two Classic Maya ballplayer panels from Tipan Chen Uitz, Belize

Christopher R. Andres, Christophe Helmke, Shawn G. Morton \& Gabriel D. Wrobel

New radiocarbon dates and the herder occupation at Kasteelberg B, South Africa

Karim Sadr, C. Britt Bousman, Thomas A. Brown, Kamela G. Sekonya,

Elias Sideras-Haddad \& Andrew B. Smith

Integrating the Old World into the New: an 'Idol from the West Indies'

Joanna Ostapkowicz, Fiona Brock, Alex C. Wiedenhoeft, Rick Schulting \&

Donatella Saviola 
Glass and stoneware knapped tools among hunter-gatherers in southern Patagonia and Tierra del Fuego

Amalia Nuevo Delaunay, Juan Bautista Belardi, Flavia Carballo Marina, María José Saletta \& Hernán De Angelis

\section{Method}

Semi-automated detection of looting in Afghanistan using multispectral imagery and principal component analysis

Anthony Lauricella, Joshua Cannon, Scott Branting \& Emily Hammer

\section{Debate}

Agents and commodities: a response to Brughmans and Poblome (2016) on modelling 1356 the Roman economy

Astrid Van Oyen

The case for computational modelling of the Roman economy: a reply

to Van Oyen

Tom Brughmans \& Jeroen Poblome

Our fourth Lascaux

N. James

\section{Book reviews}

\section{Review articles}

Archaeology, archaeozoology and the study of pastoralism in the Near East CANAN ÇAKIRLAR

Revolutions in the desert: the rise of mobile pastoralism in the southern Levant Steven A. Rosen

Bones and identity: zooarchaeological approaches to reconstructing social and cultural landscapes in Southwest Asia Reuven Yeshurun, Lior Weissbrod, Nimrod Marom \& Guy Bar-Oz (ed.)

Fortifications in the ancient Mediterranean and Near East

Jesús GaRCía SÁNCHEZ

Ancient fortifications: a compendium of theory and practice Silke Muth, Peter Schneider, Mike Schnelle \& Peter De Staebler (ed.)

Focus on fortifications: new research on fortifications in the ancient Mediterranean and the Near East Rune Frederiksen, Silke Muth, Peter Schneider \& Mike Schnelle (ed.)

Mycenaeans in Bavaria? Amber and gold from the Bronze Age site of Bernstorf Anthony Harding \& Helen Hughes-Brock

Bernstorf: Archäologisch-naturwissenschaftliche Analysen der Gold-und Bernsteinfunde vom Bernstorfer Berg bei Kranzberg, Oberbayern Rupert Gebhard \& Rüdiger Krause 


\section{Book reviews}

Richard E. Blanton, with Lane F. Fargher How humans cooperate: confronting the challenges of collective action

JUSTIN JENNINGS

Hein B. Bjerck, Heidi Mjelva Breivik, Silje E. Fretheim, Ernesto L. Piana, Birgitte

Skar, Angélica M. Tivoli \& Francisco J. Zangrando (ed.) Marine ventures:

archaeological perspectives on human-sea relations

YAROSLAV V. KUZMIN

John J. Shea Stone tools in human evolution: behavioral differences among technological primates

Michael J. WALKeR

Graeme Barker \& Lucy Farr (ed.) Archaeological investigations in the Niah Caves,

Sarawak

Charles Higham

Dušan Borić Deathways at Lepenski Vir: patterns in mortuary practice

JOHN CHAPMAN

Thomas X. Schuhmacher Elfenbeinstudien Faszikel 3: Elefanten und Elfenbein auf der

Iberischen Halbinsel und in Nordwestafrika

DIRK WICKE

Álvaro Fernández Flores, Leonardo García Sanjuán \& Marta Díaz-Zorita Bonilla (ed.)

Montelirio: un gran monumento megalítico de la Edad del Cobre

KaTINA T. LILLIOS

Rachel Opitz, Marcello Mogetta \& Nicola Terrenato (ed.) A mid-Republican house from Gabii

STEFANO CAMPANA

Caroline M. Stuckert (ed.) The people of early Winchester

SAM LUCY

Mick Atha \& Kennis Yip Piecing together Sha Po: archaeological investigations and landscape reconstruction

JOHN MiKSIC

\section{New Book Chronicle}

Robert Witcher 


\section{Project Gallery on the website (http://www.cambridge.org/core/journals/antiquity/ project-gallery)}

The first Middle Palaeolithic site exhibiting obsidian industry on the northern slopes of the Central Caucasus

Ekaterina Doronicheva, Liubov Golovanova, Vladimir Doronichev, Andrey Nedomolkin \& Steven Shackley

http://dx.doi.org/10.15184/aqy.2017.171

Archaeological reconnaissance of the Late Pleistocene Red Sea coast in the Danakil Yonatan Sahle \& Amanuel Beyin

http://dx.doi.org/10.15184/aqy.2017.172

'Forest Moss': no part of the European Neanderthal diet

James H. Dickson, Klaus Oeggl \& Daniel Stanton

http://dx.doi.org/10.15184/aqy.2017.165

New research on the Late Pleistocene in the Lim Channel, Istria

Ivor Janković, Darko Komšo, James C.M. Ahern, Rory Becker, Katarina Gerometta, Jacobo Weinstock, Antonela Barbir, Nikola Vukosavljević, Barbara Cvitkušić, Krunoslav Zubčić, Sanjin Mihelić \& Fred H. Smith

http://dx.doi.org/10.15184/aqy.2017.170

Flint quarrying in north-eastern Iberia: quarry sites and the initial transformation of raw material

Xavier Terradas \& David Ortega

http://dx.doi.org/10.15184/aqy.2017.167

The origins of metallurgy in China

Lin Meicun \& Xiang Liu

http://dx.doi.org/10.15184/aqy.2017.177

A palimpsest grave at the Iron Age cemetery in Estark-Joshaqan, Iran Javad Hosseinzadeh, Mohsen Javeri, Majid Montazerzohouri, Ali Banitaba, Reza Nori Shadmahani, Leila Makvandi \& Arkadiusz Sołtysiak

http://dx.doi.org/10.15184/aqy.2017.168

Towards a landscape archaeology of Buddhist cave-temples in China

Francesca Monteith

http://dx.doi.org/10.15184/aqy.2017.169

A recent reconnaissance of the central Helmand Valley

Marc A. Abramiuk

http://dx.doi.org/10.15184/aqy.2017.173 


\section{The afterlife of Egyptian statues: a cache of religious objects in the temple of Ptah at Karnak}

Guillaume Charloux ${ }^{1, *}$, Christophe Thiers ${ }^{1}$, Mohammad Abd Al-Aziz ${ }^{1}$, Mona Ali Abady Mahmoud ${ }^{1}$, Stéphanie Boulet ${ }^{2}$, Camille Bourse $^{1}$, Kevin Guadagnini ${ }^{1}$, Juliette Laroye ${ }^{1}$ $\&$ Ahmed Mohammed Sayed ElNasseh ${ }^{1}$

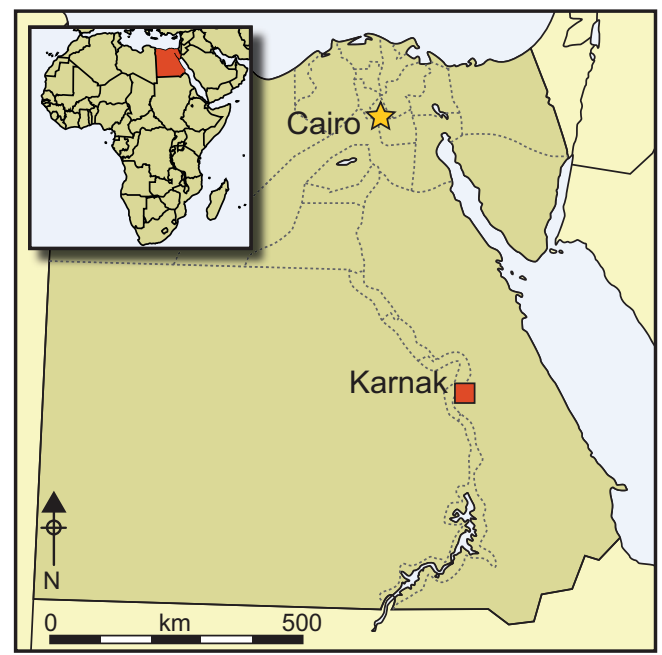

The relationship of statues to the deities they represent is reflected in the special treatments they were often accorded during and after their primary use and display. In 2014 an unusual favissa-an intentionally hidden cache of religious objects—was discovered in the temple of Ptah at Karnak in Egypt. Such caches are generally poorly documented and difficult to date. The favissa contained numerous fragmentary statuettes and figurines, including 14 representing Osiris, carefully arranged around a larger central statue of Ptah. By comparing this cache with evidence from other Egyptian favissae, a hypothesis is proposed to explain the creation of such caches: the Osirian burial of an artefact, in this case the deposition of the 'deceased' statue of the god Ptah and its assimilation with Osiris, the god of rebirth.

Keywords: Egypt, Karnak, Ptah, favissa, cache

\section{Introduction}

Every year, discoveries of ancient Egyptian monuments and artworks are widely disseminated across the media, providing further evidence for the cultural and spiritual richness of ancient Egypt. 'Caches'-deposits of intentionally hidden artefacts-figure

1 French-Egyptian Centre for the Study of the Temples of Karnak, Egyptian Ministry of Antiquities, CNRS/USR 3172, BP 63, Luxor, Egypt

2 LabEx Archimede, University Paul-Valéry Monpellier 3, Site Saint Charles, Route de Mende, F-34199 Montpellier cedex 05, France

* Author for correspondence (Email: guillaume.charloux@cnrs.fr) 
among discoveries that particularly stimulate the collective imagination and the interest of researchers. The practice of caching is well evidenced in Egypt and the Near East, dating to the Predynastic and even the Neolithic periods (e.g. Williams 1982; Freikman \& Garfinkel 2009). Many types of cache have so far been discovered, from caches of mummies and sarcophagi, to statues, papyri and jewels, to more modest, sometimes mixed, deposits of coins, ostraca and embalming instruments (e.g. Maspero 1881; Quibell 1898: 3; Legrain 1906; Kamel 1968; Hegazy \& Van Siclen 1989; Reddé et al. 1992; Eaton-Krauss 2008; Wahby Taher 2011; Faucher et al. 2017). These numerous deposits do not all fulfil the same function $(s)$ - many functional categories are found in the literature. These include funerary, 'cultic' or votive caches, caches for storage, preservation, execration or consecration; and also foundation deposits and treasures- the definition and identification of which are not always clearly established.

Although they represent some of the most spectacular discoveries, caches of sacred objects are particularly poorly documented. In Egypt and neighbouring regions, their role was to preserve, inside the temple precinct, and thus concealed from impious eyes, divine statues, ex-votos, cultic instruments and furniture consecrated in the sanctuaries. Religious items, well known from inventories made by the clergy throughout Egyptian history (Cauville 1987), retained their sacred character and power and required protection from any exterior intrusion. Upon going out of use, these artefacts were gathered in an enclosed space by the temple priests, being the only individuals authorised to manage this type of religious material.

Caches of sacred objects are divided into three main groups, differentiated according to context: pits, also known as favissae (e.g. Legrain 1905; Saghir 1992; Coulon 2016a); caches in foundation trenches (e.g. Robichon et al. 1954: 34; Charloux 2012); and socalled 'built' caches, such as a niche, a reinforcement in the masonry of a building, or a specific built structure, for example, in a well or cistern (e.g. Quibell \& Green 1902: 27; Thiers 2014). The caches of religious artefacts discussed here represent deposits in secondary contexts only. Thus, furnishings and statues in primary contexts (e.g. in official religious spaces, in a domestic sanctuary or in a tomb) are excluded from this category.

Caches of religious artefacts are distinguishable from other categories of caches, in particular 'treasure', which would be identified here as a 'safety deposit' (Vernus 1989). This comprises a group of objects whose value is more economic than cultic (e.g. ingots, coins, jewels) and which were buried with the intention of being retrieved at a later date. 'Foundation deposits' are also composed of sacred artefacts placed in pits, but in a primary context: the artefacts are often quite small and of standardised composition, and were intended for the commemoration and protection of the buildings under which they were buried (Weinstein 1973; Schmitt 2015).

Caches of sacred objects were unlikely to have been temple 'dustbins' with no specific purpose; the burial of sacred artefacts was probably accompanied by ceremonies, the exact nature of which is unknown due to the absence of descriptive historical sources. Contrary to many other events in the religious life of the temple, the rites and practices surrounding these caches do not seem to have been the subject of textual or iconographic descriptions (but see Coulon 2016b). The archaeological study of these

(C) Antiquity Publications Ltd, 2017 
particular assemblages should, therefore, illuminate the actions and intentions of those who buried the objects, and the associated ceremonial rites (Jambon 2016). Unfortunately, due to a lack of published field data, it is as difficult to characterise and classify these deposits typologically as it is to date them. Excavations around the temple of Ptah in Karnak, Egypt, have recently provided the fortuitous opportunity for a detailed study of an in situ favissa cache. These excavations are part of the permanent CFEETK research project (Ministry of Antiquities, Egypt; USR3172 of the CNRS, France), and the discovery has led to the formulation of new hypotheses concerning the raison d'etre of these rich assemblages.

\section{Area and method of study}

The temple of Ptah is located at the northern edge of the domain of Amun-Re in Karnak (Figure 1). Erected during the New Kingdom by Thutmosis III (Eighteenth Dynasty), the present monument was built over an older structure (Thiers 2013; Charloux \& Thiers 2017). The temple was modified during the course of the New Kingdom, before more extensive refurbishment changed its layout during the first millennium BC (Biston-Moulin \& Thiers 2016) (Figures $2 \& 3$ ). The space inside the temple precinct was finally occupied by civilian installations in the Ptolemaic and Roman-Byzantine periods (David 2013; Durand 2015).

The favissa was discovered in December 2014, less than $3 \mathrm{~m}$ behind the edifice of Thutmosis III, $1.75 \mathrm{~m}$ south of the mudbrick enclosure of Nectanebo I (Figure 4). It quickly became clear that a series of earlier reconstructions had disturbed the area. Excavation revealed that the favissa had been intentionally dug between two long brick walls running north-south. They were probably placed here as a preparatory structure for the laying of paving that no longer exists. The favissa and the brick wall to the west would, therefore, have been covered by paving slabs.

The oval-shaped pit measured $1.46 \mathrm{~m}$ north-south and $1.05 \mathrm{~m}$ east-west. Its vertical sides were exposed to a depth of almost $1 \mathrm{~m}$ (Figure 5). The upper part was partially restituted by the CFEETK archaeologists, notably on its south-west side, which was destroyed due to recent disturbances. Three distinct layers of clayey and dense silt filled the favissa. The bottom of the pit, upon which was placed the statue of Ptah, comprised a layer of yellow desert sand from a lower level (i.e. the pit cut into previous archaeological contexts). Several fragments of inlay were found by systematic sieving with a $7 \mathrm{~mm}$ mesh. Photogrammetry at each stage of the excavation was used to create 3D reconstructions of the exact in situ artefact positions. Field photographs were also assembled and adjusted using Photoscan software, with an accuracy of $\leq 10 \mathrm{~mm}$ using topographic points (three to five points per stage) taken by a robotic Leica TPS1200+ total station. A 3D model of the favissa was then created with 3DSMax software using field data and the objects themselves (recreated by this photogrammetric method), following restoration. This systematic process was necessary, as it was impossible to leave the artefacts in situ once they had been exposed; the local authorities required them to be moved into secure storage at the end of each day. Immediate conservation was provided by a team of CFEETK conservators (Figure 6).

(C) Antiquity Publications Ltd, 2017 


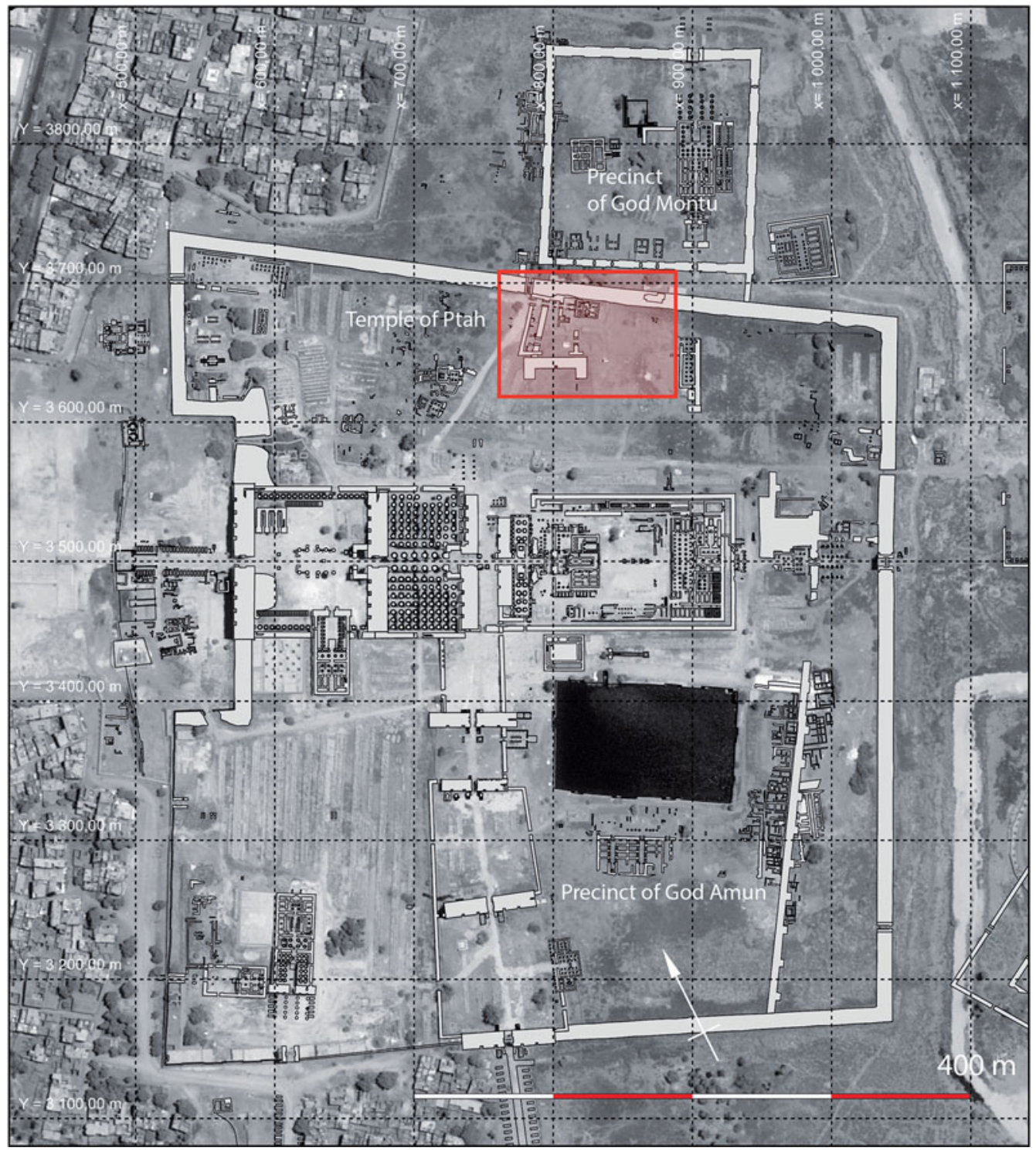

Figure 1. Plan of the temple of Amun in Karnak and the area under study (@ CFEETK-CNRS-MoA: G. Charloux, K. Guadagnini).

\section{The objects and stages of deposition}

The favissa contained 38 objects made of limestone (some gilded), greywacke, probably wood (but completely lost), copper alloy, faience and Egyptian frit (Figure 7), as follows:

(C) Antiquity Publications Ltd, 2017 


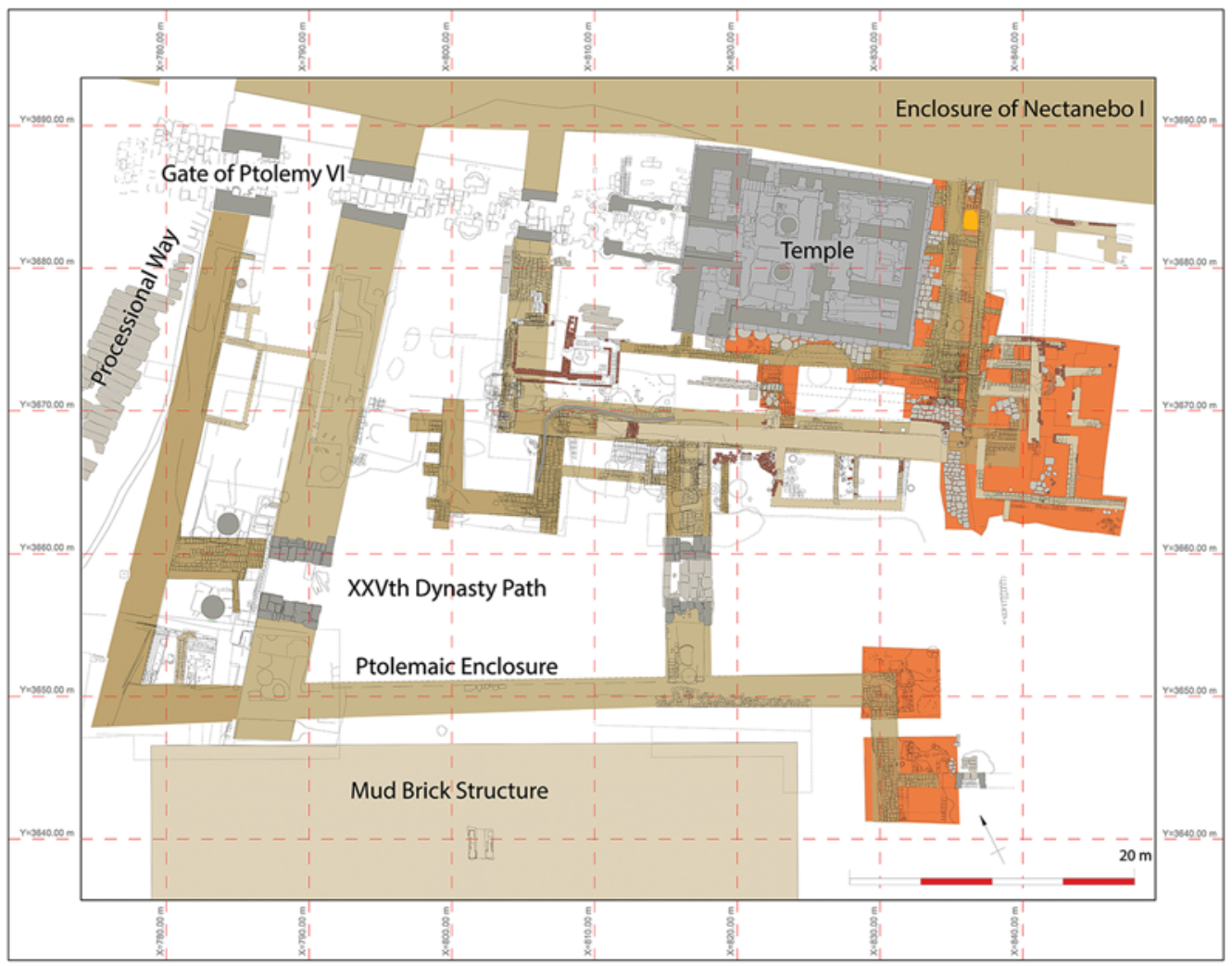

Figure 2. The sector of the temple of Ptah showing the areas excavated in 2015 (@) CFEETK-CNRS-MoA: M. Abady Mahmoud, G. Charloux, K. Guadagnini, P. Zignani et al.).

- Fourteen statuettes and figurines of Osiris;

- Eleven fragments of inlay (iris, cornea, false beard, cap, strand of hair, inlay plaque) from statues;

- Three baboon statuettes (representing the god Thoth);

- Two statuettes of the goddess Mut (one with hieroglyphic inscriptions);

- Two unidentified statuette bases;

- One head and one fragmentary statuette of a cat (Bastet);

- One small fragmentary faience stele recording the name of the god Ptah;

- One head of a statuette of a man in gilded limestone;

- One lower part of a statue of the seated god Ptah, sawn and repaired;

- One sphinx;

- One unidentified metal piece.

With one exception, all of the artefacts were fragmentary, having been damaged in antiquity. 


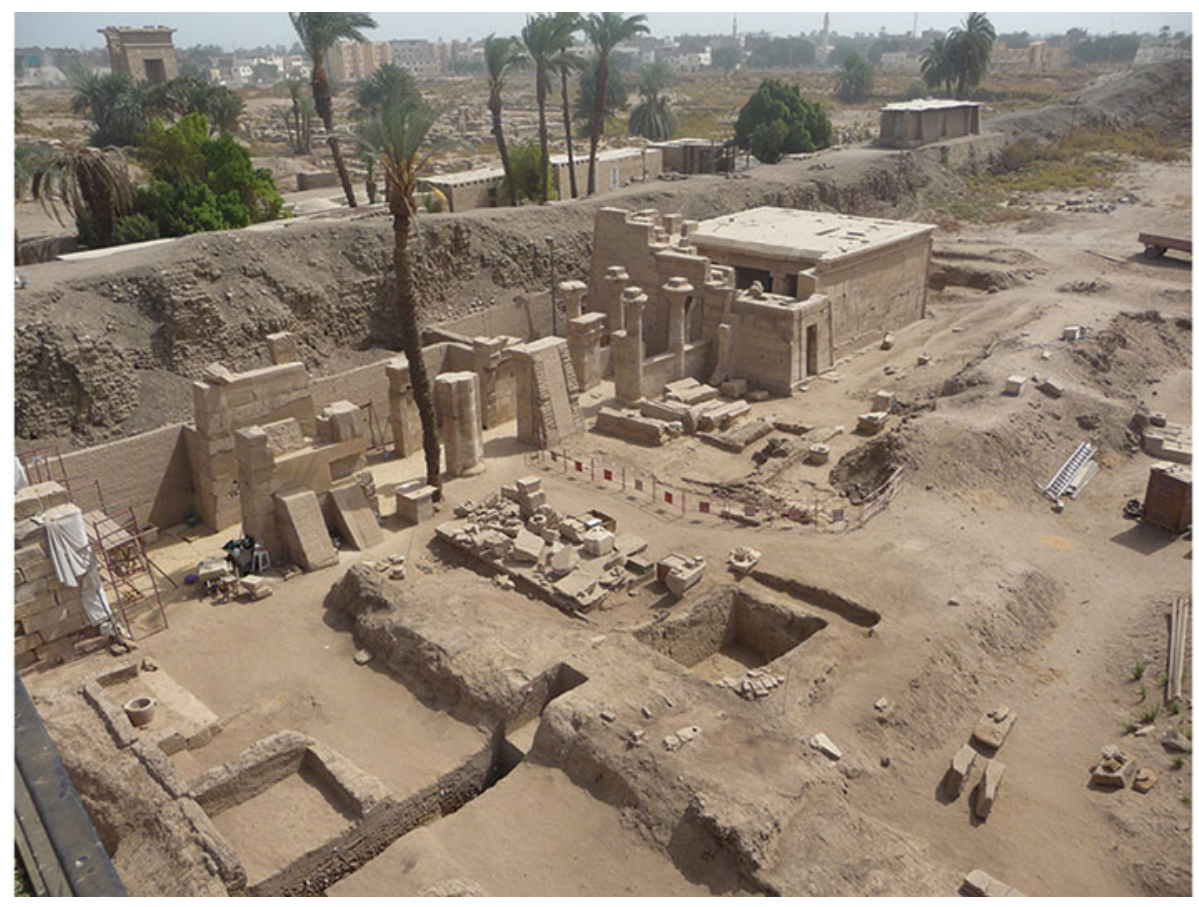

Figure 3. Overview of the temple of Ptah in Karnak (@ CFEETK-CNRS-MoA: J.-Fr. Gout).

Four stages of the burial sequence were identified:

1. First, the digging of the favissa had cut through three older levels, including an earlier pit. The available evidence suggests that the size of the original pit had been constrained by the adjacent mudbrick walls.

2. Next, the artefacts were placed in the bottom of the favissa. The first artefact deposited was the lower part of the limestone statue of the seated god Ptah, lying on its right side. Given the depth of the pit and the weight of the statue, there is no doubt that this statue was positioned manually by at least two or three individuals. The statue was intentionally placed in the south-east portion of the pit to leave space for a wooden effigy of the god Osiris (Figure 8), of which only the decorated surface coating and elements of the appliquéd metal (beard and two feathers of the Atef Crown) have survived. Several concentrations of painted and gilded coating suggest the presence of other organic statues or statuettes, long since disappeared. The other artefacts were then distributed evenly around and above the statue of Ptah during backfilling of the favissa (Figure 9).

3. In the third stage, over $200 \mathrm{~mm}$ of backfill was deposited before the small limestone sphinx statue was placed in the north-east area of the pit.

4. Finally, there were two more depositions of soil before a small male head was placed in the upper layer. The cut edges of the pit at the level of this head were not observed in the field, due to subsequent disturbance. The nature and position of the head in the upper

(C) Antiquity Publications Ltd, 2017 


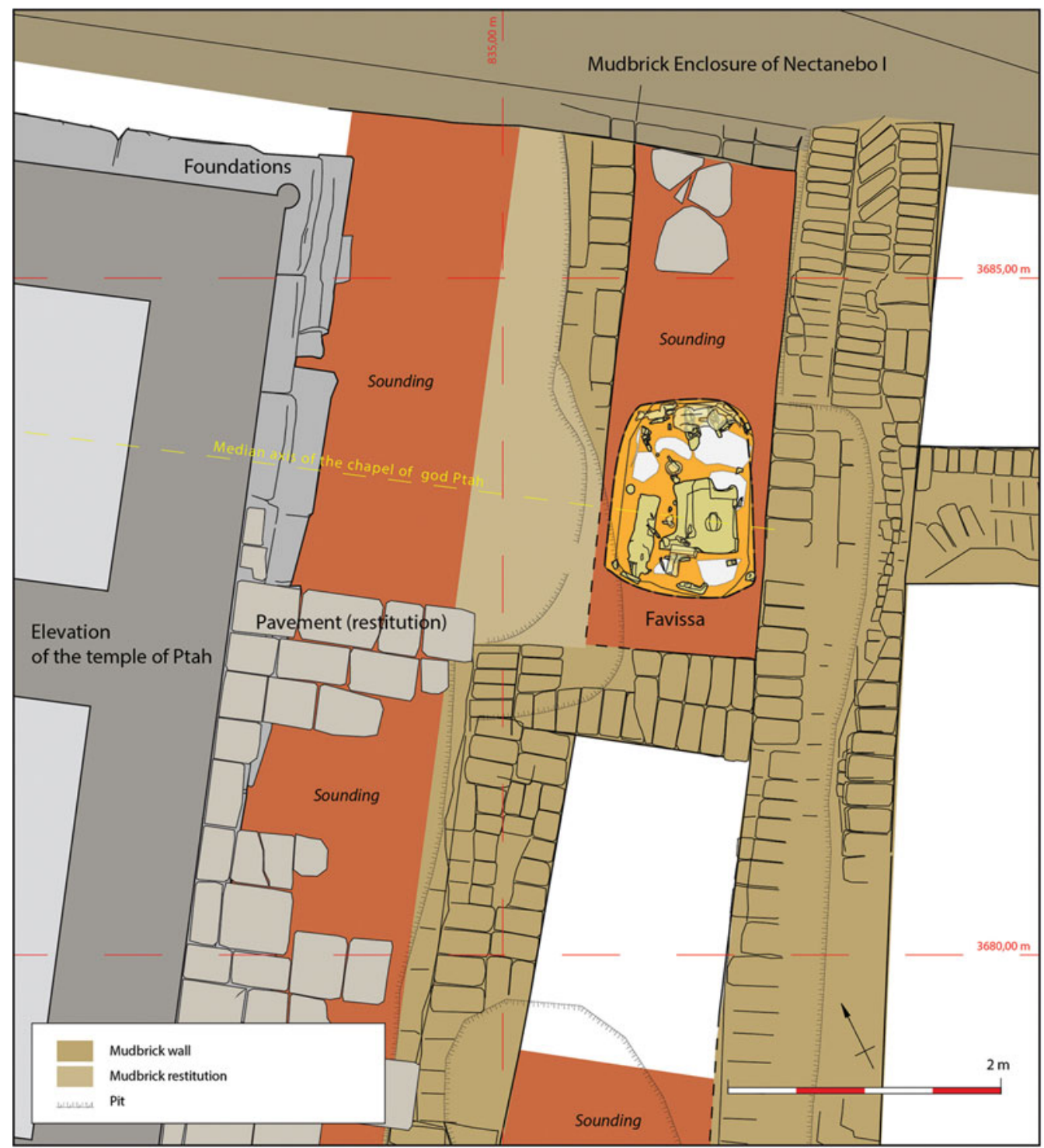

Figure 4. The favissa in its archaeological context, at the back of the temple of Ptah (C) CFEETK-CNRS-MoA: G. Charloux, K. Guadagnini).

layer of the favissa, between the first courses of the brick wall, however, leave little doubt as to its association with the deposit of statues below.

Despite the layered character of the deposit, a detailed inspection of the stratigraphy does not indicate any later disturbance following the burial. As with numerous other favissae, it clearly highlights the ephemeral character of the act of burying such objects (e.g. Quibell \& Green 1902: 34-35; Legrain 1905: 66). 
Guillaume Charloux et al.

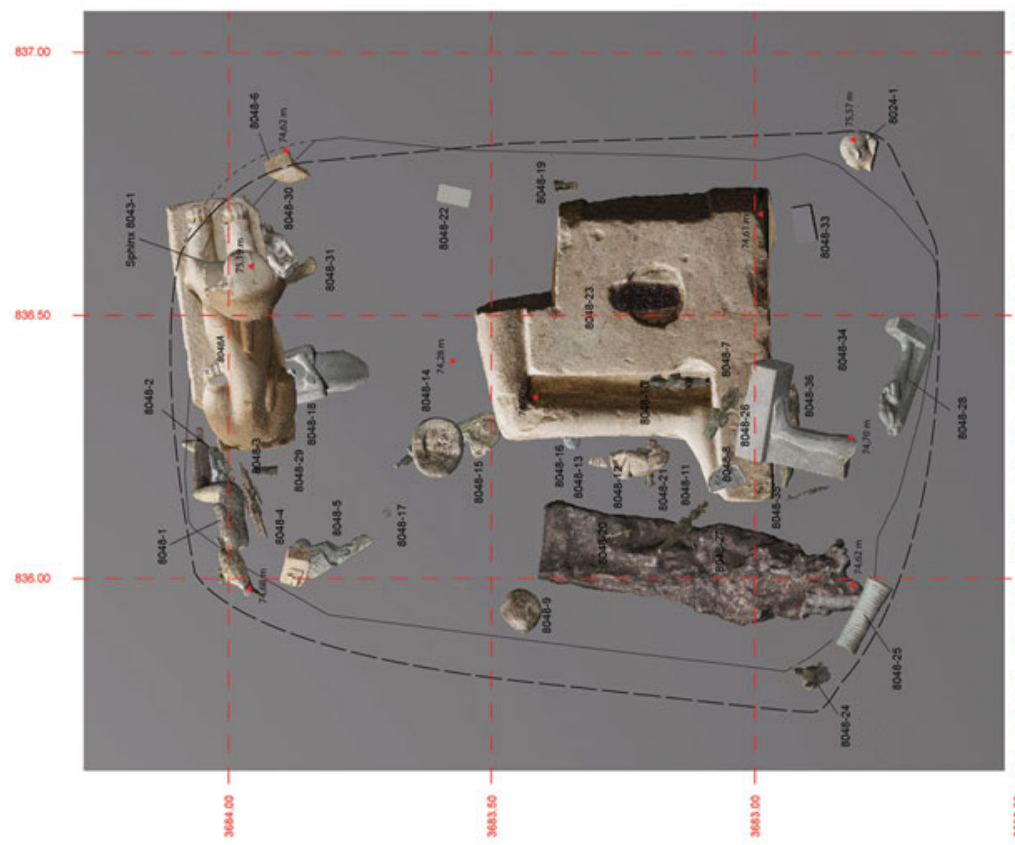

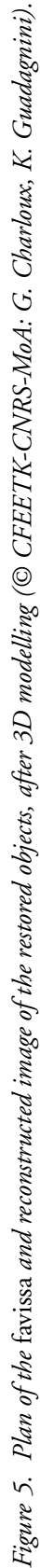

(C) Antiquity Publications Ltd, 2017 


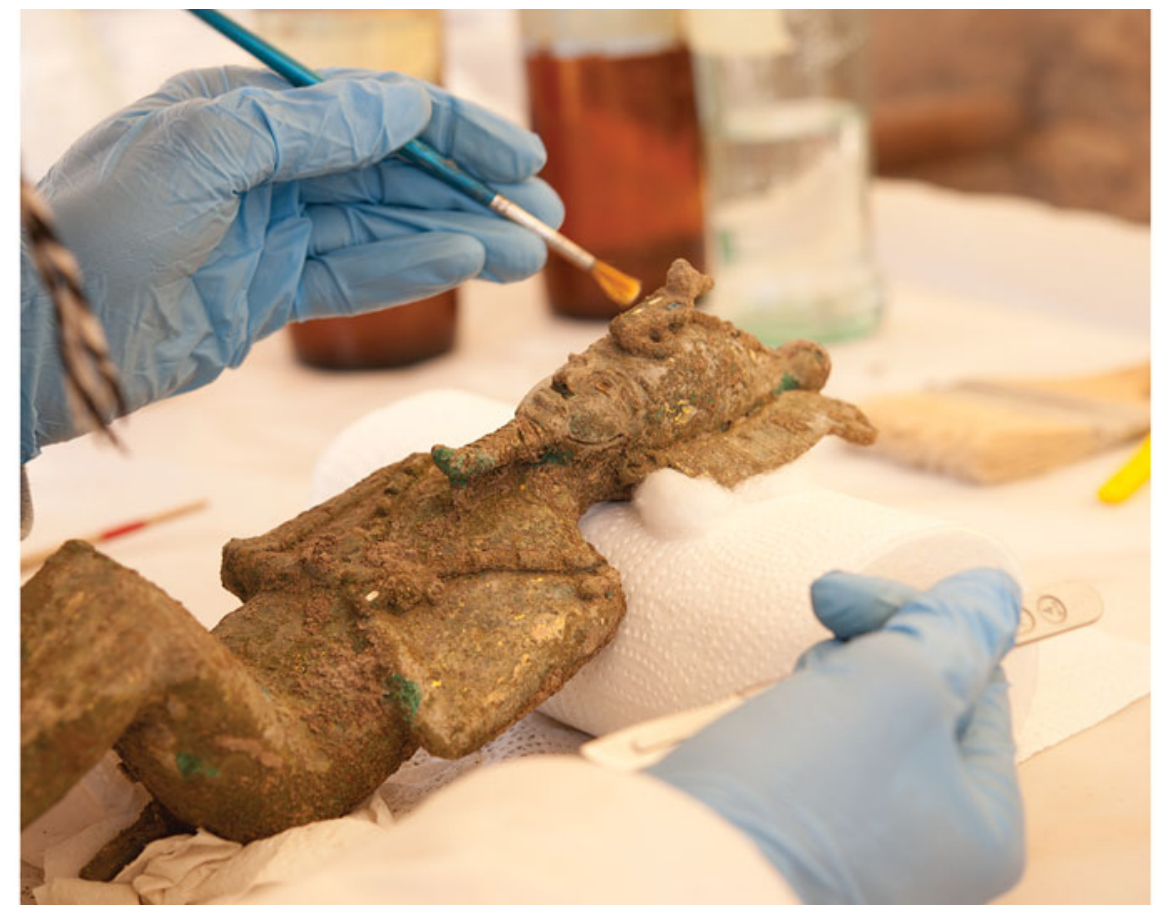

Figure 6. Conservation of an Osiris statuette (@ CFEETK-CNRS-MoA: J. Maucor).

\section{Discussion}

\section{Dating}

Favissae are generally difficult to date accurately: the items in the pit provide, at best, a terminus post quem for its digging, whereas the archaeological levels sealing it, when extant, provide a terminus ante quem. The artefacts from the Ptah favissa had been used for a long time before being deposited. The fragmentary statue of Ptah dates back to the New Kingdom, probably to the pre-Amarna period, as evidenced by other restored examples (Barbotin 2011). A Third Intermediate Period/Late Period date (Twenty-fifth to Thirtieth Dynasties) is suggested for the statuettes and figurines, mainly through stylistic comparisons of the two greywacke statuettes of Osiris and the inscriptions on a statuette of Mut. The small statue of the sphinx, however, tells a slightly different story; its general appearance, the shape of the face and eyes and the modelling of the muscles support a late Ptolemaic date, whereas the gilded male head may date the artefact to the early Ptolemaic period. This supports the conclusions of the pottery analysis, which dates a few sherds to early Ptolemaic times among a vast majority of Late Period wares. This confirms the stratigraphic analysis: the paving and the southern door of the temple façade were most probably installed in the Ptolemaic period. Thus, it is reasonable to conclude that the artefacts were removed from the sanctuary and then buried by its priests in the second half of the Ptolemaic period, around the second century to the middle of the first century BC. 

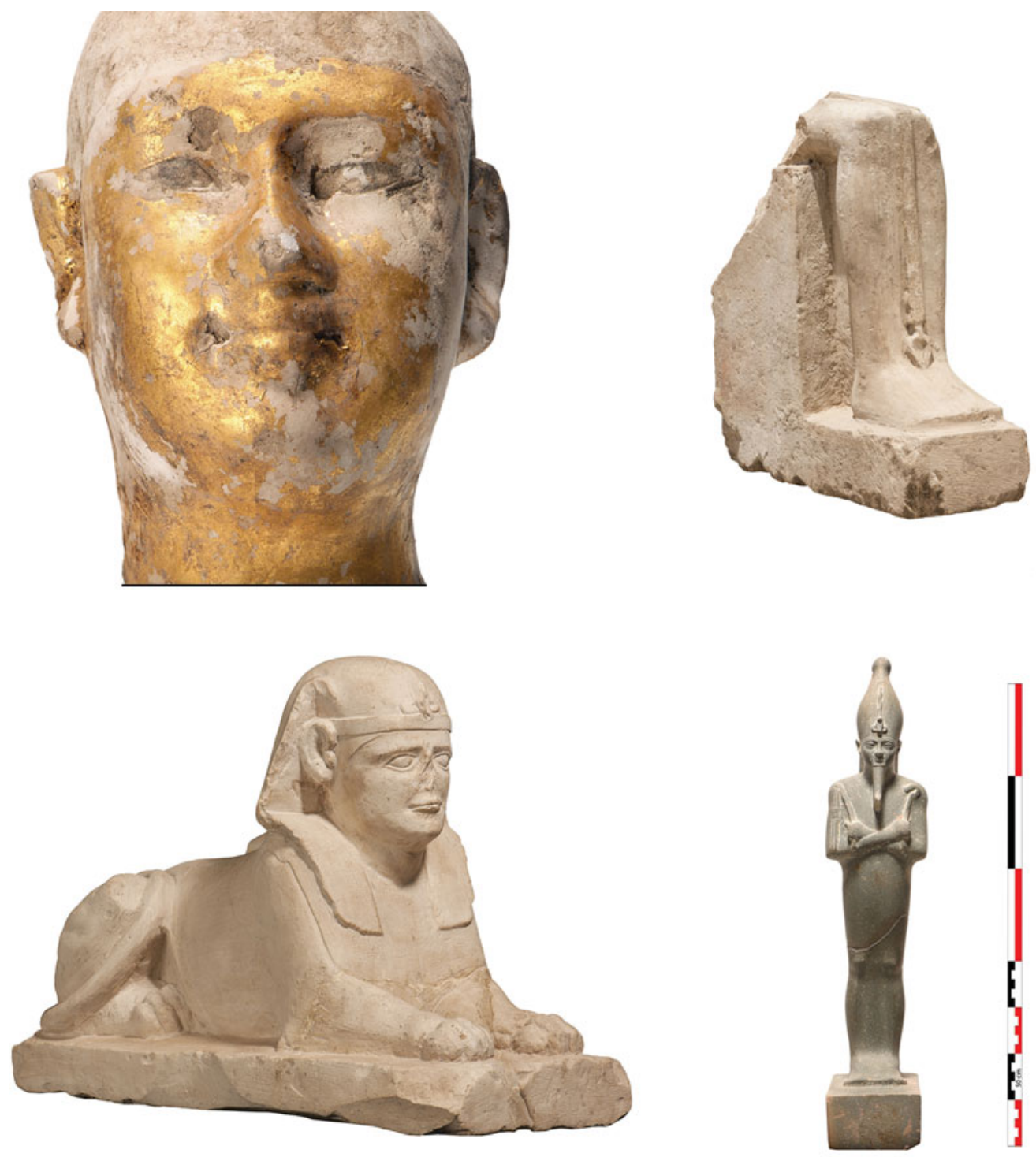

Figure 7. Main artefacts discovered: top left) male head; top right) lower part of the limestone statue of the god Ptab; bottom left) limestone sphinx; bottom right) small statue of Osiris (@ CFEETK-CNRS-MoA: J. Maucor).

\section{The statue of the god Ptah and its physical and symbolic protection}

The central positioning of the fragmentary statue of Ptah on the base of the favissa indicates that this was the main object in the deposit. Moreover, being larger than the other figures (see Traunecker 2004: 52), it represents the only cultic statue in the favissa (with the possible exception of the faience beard from another large statue). The statue of Ptah was also facing west, meaning that it was positioned on the central axis of the north chapel of the

(C) Antiquity Publications Ltd, 2017 
sanctuary, where, in antiquity, the cultic statue of the god Ptah was placed. Other artefacts support a link between the favissa and the neighbouring temple: the presence of four caps in blue faience-attributes of Ptah_and a small faience stele recording the name and a representation of Ptah. Taking these elements into account, it is reasonable to suggest that the statue of the god was originally housed in the neighbouring sanctuary.

The intentional layering of the artefacts and the care taken over their relative distribution must have been the product of well-established rituals, a few characteristics of which can be discerned:

First, there is the particular care accorded to the protection of the central effigy. Deposited on a layer of yellow sand, the divine statue was 'wrapped' in a protective 'cloak' of small, damaged votive images, which surround it on all sides and above.

The middle stage of the favissa was placed under the protection of the sphinx, a wellknown mythical guardian, which was facing eastwards towards the sunrise. The presence of

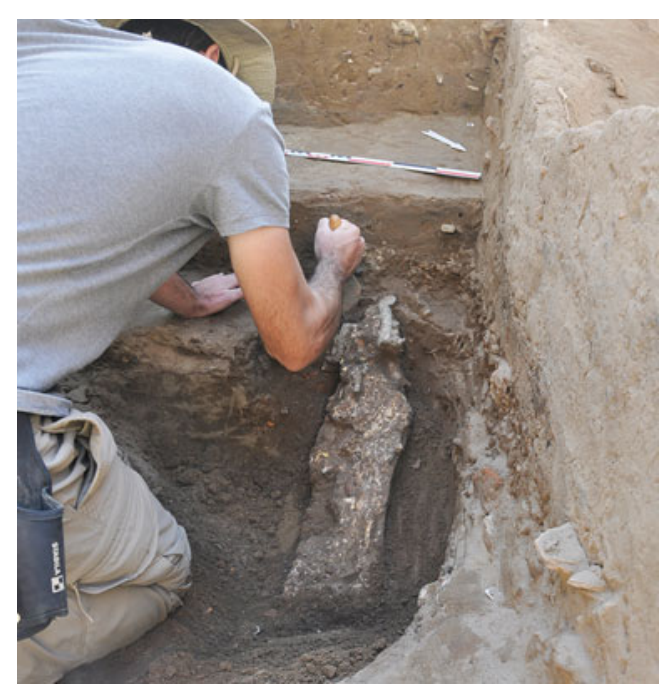

Figure 8. Excavating the remains of the covering of a wooden statuette of Osiris (C) CFEETK-CNRS-MoA: M. Abady Mahmoud). a protective guardian in the form of a sphinx, or sometimes a lion or jackal (Anubis), occurs sufficiently often to consider it a common element in statue caches (e.g. at Saqqara North (Emery 1967: pl. XXI, no. 2) or at Karnak North (Robichon et al. 1954: 34, fig. 65); see also Coulon 2016b: 33-34, fig. 12). This hypothesis is substantiated by the high proportion of these effigies in votive contexts (Pinch \& Waraksa 2009: 5). If it is indeed associated with the favissa, the male head perhaps represents an additional stage of protection. Finally, paving most probably sealed the items in the favissa, as seen in other caches of this type (see Jambon 2016: 157).

Another important observation addresses the 'mutilation' of the artefacts in the favissa-or at least the fact that they were invariably fragmentary or damaged. This is a recurring phenomenon in this type of deposit, as recorded by virtually all excavators (e.g. Chassinat 1921: 56-57; Mond \& Myers 1940: 49). It has been suggested that these statue caches were made following catastrophic events (e.g. fire or earthquake), invasion or conflict, religious change, cleaning of a cluttered sanctuary, or simply following the deterioration of the cultic objects (Bonnet \& Valbelle 2005: 174). Distinguishing between various events and phenomena such as these, using archaeological evidence, however, remains difficult. It should be remembered that the criteria determining when statues went out of use in ancient Egypt are unknown. Although it is usually difficult to identify events that led to breakages, it is nonetheless obvious that some breakages occurred well before the artefact was deposited in a cache; this is the case, for example, with one statuette of Mut in the Ptah favissa cache (Figure 10), and for statues

(C) Antiquity Publications Ltd, 2017 


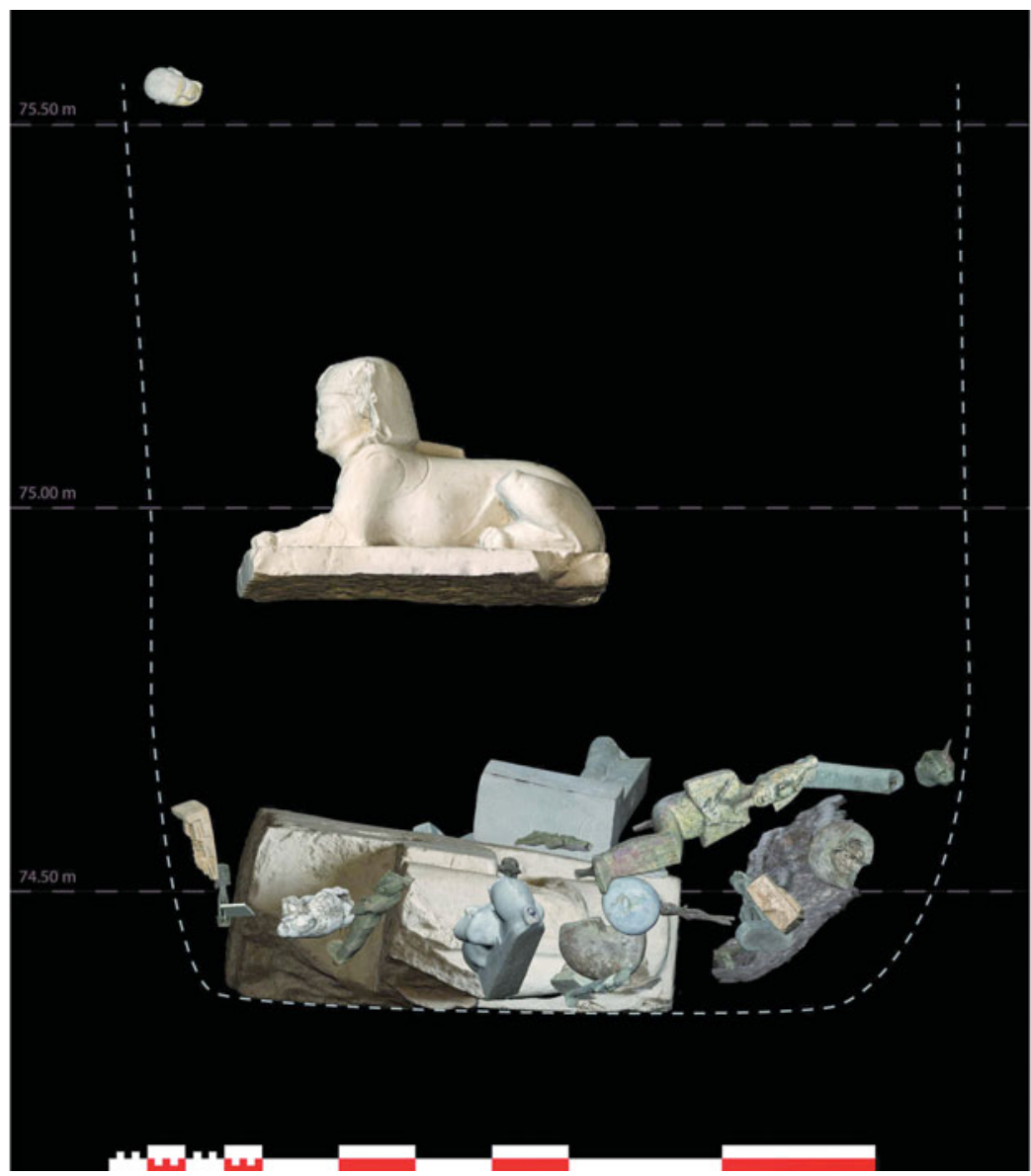

Figure 9. Reconstructed cross-section of the favissa looking south (after 3D modelling of the restored objects) (@ CFEETKCNRS-MoA: K. Guadagnini).

of Amun in the favissa of Luxor (Saghir 1992: 16). The latter shows evidence of ancient restoration, recognisable as cracks filled with mortar. Equally, it is known through numerous textual attestations that the 'political' destruction of statues was clearly supported in Egypt (Boraik 2007), the Levant and Mesopotamia (Ben-Tor 2006). It can also be assumed that some damage resulted from the act of deposition, although it would be difficult to infer any ritual motivation for such damage. This may have been the case for the small sphinx statue in the favissa-its broken front left paw was placed against the front part of its body; the object may have been broken during its deposition. Equally, there are quite specific cases of the crumbling of statues that are difficult to ascribe to political or accidental events (e.g. Robichon et al. 1954: 47).

Damage to the physical integrity of statues can be quite remarkable. At Deir el-Bahari, for example, the figures of Mentuhotep II and Amenhotep I were systematically decapitated, and the heads and bodies buried in pits far away from each other (Arnold et al. 1979;

(C) Antiquity Publications Ltd, 2017 
Szafranski 1985: 259-62). In the 1930s, Mond and Myers (1940: 16; pl. XI, fig. 1 and pl. L., fig. 2) discovered two similar cases at Armant. Here, the heads and bodies of two different colossus statues were combined to create a complete statue. These unusual examples illustrate the intentional regrouping of separate statue parts.

These lines of evidence suggest that the systematic occurrence of artefact breakage is more important than the actual reasons behind such damage. Whatever their origins, the breakages occurred before, or sometimes during, deposition. It can be deduced that the statues must have been, in some way, at the end of their 'lives' or of their use. This 'death' of a statue was a crucial influence in its deposition; were the breakages intended to 'channel' the energy of the statues (Bianchi 2014: 22), or to 'deactivate' their power? Or did the simple state of being broken confer eligibility for inclusion in the ritual? Current evidence is clearly insufficient to explain the raison d'etre of the deposits, or to determine the intentions of the depositors.

\section{A simulacrum of a tomb of Osiris}

It is well known that, in ancient Egypt, the god's statue had its own 'existence': made for the temple by craftsmen who knew about 'secret things', it was 'born' in the 'Mansion-of-Gold'

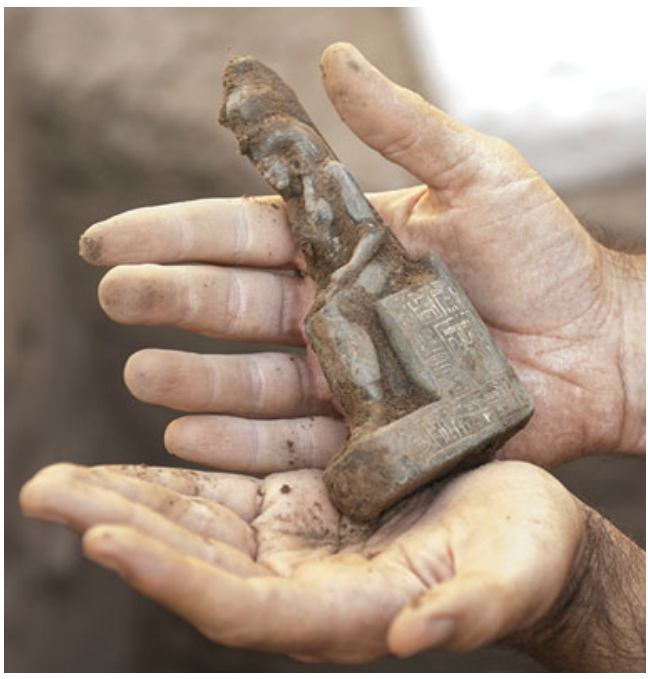

Figure 10. Statuette of Mut following excavation from the favissa (C) CFEETK-CNRS-MoA: J. Maucor). before being invested with the soul of the divinity during the ceremony of the 'opening of the mouth'. During its 'life', the statue was cared for according to the 'Daily Ritual': it was washed, coated, perfumed, dressed, fed, and the like. Various practices were added to these daily rituals, such as the regeneration of divine power by the rays of the sun. As a receptacle for the divinity, the statue also participated in annual liturgical processions and religious celebrations of the city. What happened to the divine image at the end of its use-life is more difficult to understand.

It has been suggested that the oldest effigies from the temple at Dendera were deposited, perhaps even 'immured', in the crypts of the temple itself (Cauville 1987: 112; Cauville et al. 1990: 16). A passage in the Temple Manual explains the role of the crypt: "When there is trouble on the earth, then we put the cultic images of all the gods there to distance them from it" (Quack 2004: 14). Through this role of protection and concealment, it seems that crypts and caches of objects had certain functions in common (see Vernus 2016). This dichotomy may, however, result from two successive stages in the 'life' of the divine statue or religious objects. Firstly, the crypts, sometimes considered as simulacra of the tomb of Osiris (Traunecker 2004), preserved figures in a primary context, 
where they continued to play a role in the cultic function of the temple. Secondly, the caches gathered together statues, fragments of statues or objects that were no longer in use in the temple and which were therefore deposited in a permanently sealed secondary context.

At the end of its 'life', the statue was taken out of the sanctuary and ritually buried. The inhumation was carried out by the temple priests (perhaps the "chief of rituals" or the "purifier of the god"; Quack 2010: 25) as part of an act intended to hide, protect and organise the deposit. The favissa constituted the grave of the statue, both literally and figuratively.

Assimilating the deceased with Osiris, god of the dead and lord of the hereafter, was a normal practice in ancient Egypt. We suggest that this assimilation also included the statue of the divine cult (on this subject, see Kristensen 2009), which, at the end of its life, was buried in a cache, a simulacrum of an Osirian tomb. In a recent study on the Cachette de Karnak, Jambon (2016) envisaged a funerary role for the favissae of the Luxor region, with ceremonies carried out during the burial of the statues. Equally, Szafranski (1985: 261-63) suspected a similar destiny for a statue of Amenhotep I at Deir-el-Bahari. It is, therefore, clearly no coincidence that the statue of the god Ptah was buried, fragmented and out of use, at the bottom of a pit at the back of the temple of Ptah in Karnak. Here, Ptah was assimilated with Osiris in a regeneration phase. His tomb was territory forbidden to everyone, its opening constituting a "violation of an interdiction" (Vernus 1989: 38). The omnipresence of Osiris in this type of context provided an adequate accompaniment to the figure of the god Ptah into the hereafter, thereby predicting the proper regrouping of Ptah's scattered limbs and his future rebirth (Traunecker 2004: 52).

By far the largest category of images of a god in the Ptah favissa comprised the 14 figurines of Osiris. The most remarkable was a wooden figure placed at the bottom of the pit, which has now disintegrated despite the efforts of the conservators. In fact, small bronze Osiris figures, in particular, are consistently found in Egyptian caches. A simple funerary use, however, once the statuettes had been broken, cannot be discounted. The funerary custom of accompanying the deceased with statuettes was common in ancient Egypt.

Mythical guardians (e.g. sphinx) were added in association with these Osirian effigies, as discussed above. The caches of religious artefacts—especially the more complex cachesshow, therefore, several characteristics of the Osirian burial.

The practice of burying statues in favissae cannot be dissociated from other types of pit inhumations of mummies or Osirian figurines. These include, for example, the famous Osirian 'corn-mummies' (Coulon 2014). As devotion to Osiris took multiple forms (Coulon 2010: 12), the Osirian simulacra probably showed great variation in type. The evidence discussed above suggests that the burial of sacred artefacts no longer in use, arranged around a divine statue, formed part of an extensive pattern of coherent and varied Osirian burial practices. The favissa of the temple of Ptah constitutes an exceptional example of the grave of a statue of a god situated close to its main place of worship.

\section{Acknowledgements}

This project is supported by LabEx Archimede from programme 'Investissement d'Avenir' ANR-11-LABX0032-01. We particularly wish to thank the Ministry of Antiquities of Egypt (MoA), the CNRS and the French

(C) Antiquity Publications Ltd, 2017 
Ministry of Foreign Affairs for their financial, technical and scientific support. A monograph in preparation will soon provide all of the documentation and commentaries to the preliminary results presented in this article.

\section{References}

Arnold, D., H.E. Winlock, H. Burton, W. Hauser \& G.M. Peek. 1979. The temple of Mentuhotep at Deir El-Bahari (Publications of the Metropolitan Museum of Art Egyptian Expedition 21). New York: Metropolitan Museum of Art.

BARbotin, C. 2011. Un cas antique de restauration au Musée du Louvre, in D. Valbelle \& J.-M. Yoyotte (ed.) Statues égyptiennes et kouchites démembrées et reconstituées. Hommage à Charles Bonnet: 65-71. Paris: PUPS.

Ben-Tor, A. 2006. The sad fate of statues and the mutilated statues of Hazor, in S. Gitin, J.E. Wright \& J.P. Dessel (ed.) Confronting the past: archaeological and historical essays on ancient Israel in honor of William G. Dever: 4-16. Winona Lake (IN): Eisenbrauns.

BianchI, R.S. 2014. Les bronzes égyptiens de la Fondation Gandur pour l'art. Berne: Till Schaap.

Biston-Moulin, S. \& C. Thiers. 2016. Le temple de Ptah à Karnak I. Relevé épigraphique (Ptah, nos 1-191) (Travaux du Centre franco-égyptien d'étude des temples de Karnak. BiGen 49). Le Caire: IFAO-CFEETK.

Bonnet, C. \& D. Valbelle. 2005. Des pharaons venus d'Afrique: la cachette de Kerma. Paris: Citadelles \& Mazenod.

Boraik, M. 2007. Stela of Bakenkhonsu, High Priest of Amun-Re. Memnonia 18: 119-26.

Cauville, S. 1987. Les statues cultuelles de Dendera d'après les inscriptions pariétales. Bulletin de l'Institut français d'archéologie orientale 87: 73-117.

Cauville, S.A., A. Lecler, B. Lenthéric, L. Ménassa, P. Deleuze \& P. Laferrière. 1990. Le temple de Dendera: guide archéologique. Le Caire: IFAO.

Charloux, G. (ed.). 2012. Le parvis du temple d'Opet à Karnak. Exploration archéologique (2006-2007) (Travaux du Centre franco-égyptien d'étude des temples de Karnak. BiGen 41). Le Caire: IFAO-CFEETK.

Charloux, G. \& C. Thiers. 2017. The early temple of Ptah at Karnak. Egyptian Archaeology 50: 11-15.

Chassinat, E. 1921. À propos d'une tête en grès rouge du roi Didoufrî. Monuments et mémoires de la fondation Eugène Piot 25: 53-75.
Coulon, L. 2010. Le culte osirien au I ${ }^{\mathrm{er}}$ millénaire av. J.-C. Une mise en perspective, in L. Coulon (ed.) Le culte d'Osiris au I Ir millénaire av. J.-C.: découvertes et travaux récents. Actes de la table ronde internationale tenue à Lyon, Maison de l'Orient et de la Méditerranée (Université Lumière-Lyon 2) les 8 et 9 juillet 2005 (Bibliothèque d'Études 153): 1-19. Le Caire: IFAO.

- 2014. Du périssable au cyclique: les effigies annuelles d'Osiris, in S. Estienne, V. Huet, F. Lissarague \& F. Prost (ed.) Figures de dieux: construire le divin en images: 295-318. Rennes: Presses Universitaires de Rennes.

- 2016a. La Cachette de Karnak. Nouvelles perspectives sur les découvertes de G. Legrain (Bibliothèque d'Études 161). Le Caire: IFAO-MoA.

- 2016b. Les chapelles osiriennes de Karnak. Aperçu des travaux récents. Bulletin de la Société française d'égyptologie 195-96: 16-35.

DAvid, R. 2013. La céramique d'un habitat du V $\mathrm{V}^{\mathrm{e}}$ siècle à Karnak. Cabiers de Karnak 14: 287-97.

Durand, B. 2015. Un four métallurgique d'époque ptolémaïque dans les annexes du temple de Ptah à Karnak. Cahiers de Karnak 15: 181-88.

Eaton-Krauss, M. 2008. Embalming caches. Journal of Egyptian Archaeology 94: 288-93. https://doi.org/10.1177/030751330809400115

Emery, W.B. 1967. Preliminary report on the excavations at North Saqqâra 1966-7. Journal of Egyptian Archaeology 53: 141-45. https://doi.org/10.2307/3855583

Faucher, Th., A. Meadows \& C. Lorber. 2017. Egyptian hoards I. The Ptolemies (Bibliothèque d'Études 168). Le Caire: IFAO.

Freikman, M. \& Y. Garfinkel. 2009. The zoomorphic figurines from Sha'ar Hagolan: hunting magic practices in the Neolithic Near East. Levant 41: 5-17. https://doi.org/10.1179/175638009X427567

Hegazy, E.-S. \& C.C. Van Siclen. 1989. A cache of jewellery from the edifice of Amenhotep II at Karnak. Varia Aegyptiaca 5: 227-38.

Jambon, E. 2016. La Cachette de Karnak. Étude analytique et essais d'interprétation, in L. Coulon (dir.) La Cachette de Karnak. Nouvelles perspectives sur les découvertes de G. Legrain (Bibliothèque d'Études 161): 131-75. Le Caire: IFAO-MoA.

Kamel, I. 1968. A bronze hoard at Athribis. Annales $d u$ Service des Antiquités de l'Égypte 60: 65-71. 
Kristensen, T.M. 2009. Embodied images: Christian response and destruction in Late Antique Egypt. Journal of Late Antiquity 2(2): 220-50.

Legrain, G. 1905. Renseignements sur les dernières découvertes faites à Karnak. Recueil de travaux relatifs à la philologie et à l'archéologie égyptiennes et assyriennes 27: 61-82.

- 1906. Nouveaux renseignements sur les dernières découvertes faites à Karnak (15 novembre 1904-25 juillet 1905). Recueil de travaux relatifs à la philologie et à l'archéologie égyptiennes et assyriennes 28: 137-61.

Maspero, G. 1881. La trouvaille de Deir-el-Bahari. Le Caire: Impr. française F. Mourès.

Mond, R.L. \& O.H. Myers. 1940. Temples of Armant: a preliminary survey. London: Egypt Exploration Society.

Pinch, G. \& E.A. Waraksa. 2009. Votive practices, in W. Wendrich, J. Dieleman, E. Frood \& J. Baines (ed.) UCLA encyclopedia of Egyptology: 1-9. Available at: http://escholarship.org/uc/item/ $7 \mathrm{kp} 4 \mathrm{n} 7 \mathrm{rk}$ (accessed 13 June 2017).

QuAck, J.F. 2004. Organiser le culte idéal. Le Manuel du temple. Bulletin de la Société française d'egyptologie 160: 9-25.

- 2010. Les normes pour le culte d'Osiris. Les indications du Manuel du temple sur les lieux et les prêtres osiriens, in L. Coulon (ed.) Le culte d'Osiris au $I^{e r}$ millénaire av. J.-C.: découvertes et travaux récents. Actes de la table ronde internationale tenue à Lyon, Maison de l'Orient et de la Méditerranée (Université Lumière-Lyon 2) les 8 et 9 juillet 2005 (Bibliothèque d'Études 153): 23-30. Le Caire: IFAO.

Quibell, J.E. 1898. The Ramesseum (Egyptian Research Account II). London: B. Quaritch.

Quibell, J.E. \& J. Green. 1902. Hierakonpolis II. London: B. Quaritch.

Reddé, M., J.-F. Gout \& A. Lecler. 1992. Douch IV: inventaire des objets et essai d'interprétation (Documents de fouilles de l'IFAO 28). Le Caire: IFAO.
Robichon, C., P. Barguet \& J. Leclant. 1954. Karnak-Nord IV (Fouilles de l'Institut français d'archéologie orientale 25, fasc. 1-2). Le Caire: IFAO.

SAGHIR, M. EL-. 1992. La découverte de la cachette des statues du temple de Louxor. Mainz: Philipp von Zabern.

Schmitt, Fr. 2015. La semence des pierres: le dépôt de fondation dans l'Égypte ancienne, in P. Kousoulis $\&$ N. Lazaridis (ed.) Proceedings of the Tenth International Congress of Egyptologists 2 (OLA 241): 443-58. Louvain: Peeters.

Szafranski, Z.E. 1985. Buried statues of Mentuhotep II Nebhepetre and Amenophis I at Deir el-Bahari. Mitteilungen des Deutschen Archäologischen Instituts. Abteilung Kairo 41: 257-63.

Thiers, C. 2013. Le temple de Ptah à Karnak. Remarques préliminaires, in H. Beinlich (ed.) 9. Ägyptologische Tempeltagung. Kultabbildung und Kultrealität (KSGH 3, 4): 319-42. Wiesbaden: Harrassowitz.

- 2014. Armant: recent discoveries at the temple of Montu-Re. Egyptian Archaeology 44: 32-35.

Traunecker, C. 2004. Dimensions réelles et dimensions imaginaires des dieux d'Egypte: les statues secrètes du temple d'Opet à Karnak. Ktèma 29: 51-65.

Vernus, P. 1989. Caches au trésor dans l'Égypte pharaonique Hathor. Estudios de Egiptologia 1: 33-40.

- 2016. Cachettes dans la civilisation pharaonique: de la trouvaille d'un trésor à Deir el-Médina à la mobilisation de la crypte oubliée dans l'idéologie monarchique, in L. Coulon (ed.) La Cachette de Karnak. Nouvelles perspectives sur les découvertes de G. Legrain (Bibliothèque d'Études 161): 7-20. Le Caire: IFAO-MoA.

Wahby TAher, A. 2011. News from Egypt. Ancient Egypt 64: 9-15.

Weinstein, J.N. 1973. Foundation deposits in ancient Egypt. Philadelphia: University of Pennsylvania.

Williams, B. 1982. Notes on prehistoric cache fields of lower Egyptian tradition at Sedment. Journal of Near Eastern Studies 41: 213-21. https://doi.org/10.1086/372952

Received: 20 July 2016; Accepted: 19 October 2016; Revised: 7 November 2016

(C) Antiquity Publications Ltd, 2017 